\title{
Mapping and Inventory of Forest Fires in Andhra Pradesh, India: Current Status and Conservation Needs
}

\author{
C. Sudhakar Reddy, ${ }^{1}$ P. Hari Krishna, ${ }^{1}$ K. Anitha, ${ }^{2}$ and Shijo Joseph ${ }^{2}$ \\ ${ }^{1}$ Forestry \& Ecology Division, National Remote Sensing Centre, Balanagar, Hyderabad 500 625, India \\ ${ }^{2}$ Forest and Environment Program, Center for International Forestry Research, Bogor 16115, Indonesia \\ Correspondence should be addressed to C. Sudhakar Reddy, drsudhakarreddy@gmail.com
}

Received 13 August 2012; Accepted 19 September 2012

Academic Editors: G. Martinez Pastur, P. Robakowski, and A. M. Vettraino

Copyright ( 2012 C. Sudhakar Reddy et al. This is an open access article distributed under the Creative Commons Attribution License, which permits unrestricted use, distribution, and reproduction in any medium, provided the original work is properly cited.

\begin{abstract}
Analyzing the spatial extent and distribution of forest fires is essential for sustainable forest management. The present study appraises the distribution of forest fires in one of the largest states in India, Andhra Pradesh, using satellite remote sensing. Advanced Wide Field Sensor (AWiFS) onboard on Indian Remote Sensing Satellite (IRS P6) was used for mapping and analyzing the spatial extent of burnt areas. Comparative analysis was carried out with respect to different forest types, protected areas and across elevation zones to demarcate and identify the fire-affected areas. The results show that about $19 \%\left(8594 \mathrm{~km}^{2}\right)$ of forest area were burnt in the state during 2009. Burnt area statistics for Protected Areas reveal that 24\% of forest cover was affected by fire. Nagarjunasagar Srisailam Tiger Reserve, the largest tiger reserve of the country, shows an area of $793 \mathrm{~km}^{2}(22 \%)$ under forest fire. Higher elevation areas which are predominantly dominated by savannah and woodlands experienced higher fire occurrence in comparison with lower elevation areas. Similarly, fires were prevalent near edges compared to core forest. Results of the study suggested that forests of Andhra Pradesh are prone to high fire occurrences and current fire regime poses a severe conservation threat to biodiversity both within and outside the Protected Areas.
\end{abstract}

\section{Introduction}

Fires affect the species composition, structure, pattern of vegetation, biomass, and consequently cause significant damage to the tropical forests $[1,2]$. Globally, more than 350 million ha of forests were burned in 2000, an area of nearly equal to the size of India [3]. In many tropical deciduous ecosystems, fire is part of the natural regeneration process, stimulating the germination of certain species (Teak) and clearing space for the invasion [4]. Increased burn frequencies can therefore progressively weed out more fire-vulnerable components of biodiversity. Frequent fires may cause mortality of smaller trees, opening up the canopy and leading to the gradual conversion of once-closed forests to woodland savannahs with low tree density and a grassy understory [5].

In India, large areas of tropical dry forests have already been converted to grasslands or other land use as a result of fire and other practices [6,7]. According to the Ministry of Environment and Forests, Government of India, 3.73 Mha of forests are affected by fires annually in India [8]. The extent of these fires depends on various factors such as the frequency of human disturbances and the climate of the region [9]. Forest dependent communities burn forests for shifting cultivation or to promote the growth of fresh fodder for grazing, and to facilitate the collection of non timber forest products [10]. Beddome [11] described the effects of increased burn frequencies under slash-and-burn cultivation in the states of Andhra Pradesh and Orissa. These forests have a wretched and stunted appearance, are very dry, and more or less impenetrable from a tangled rank undergrowth, and there are no seedlings, nothing, in fact, but the coppice growth generally of not only the quicker growing but also poorer sorts of timber. Brandis [12] observation from Indian forests suggested that the dominance of certain thick-barked species, or species that are able to resprout vegetatively in fire affected forests.

There is no comprehensive data available on different dimensions of fire on a regular basis in India [8]. There is 

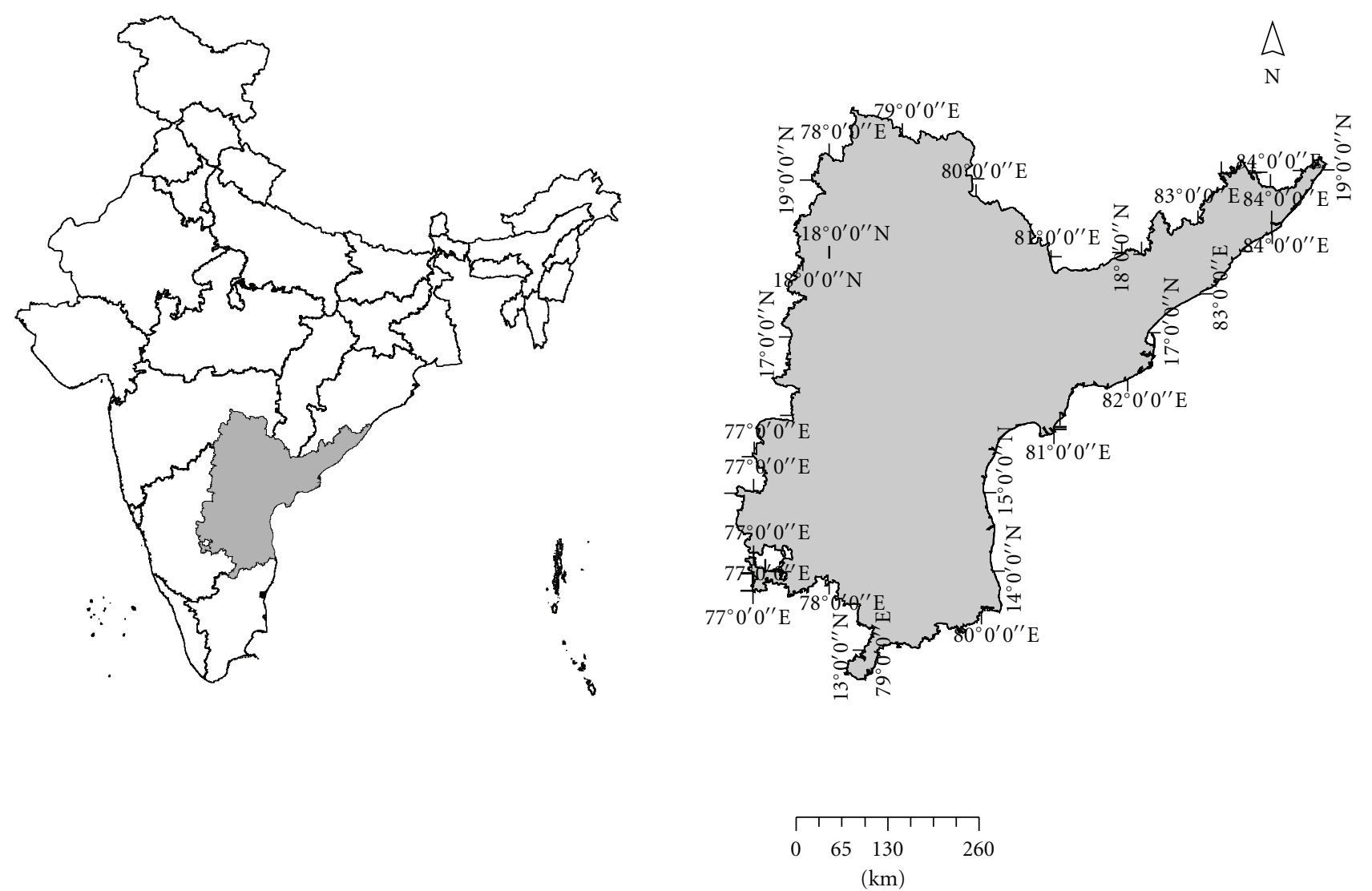

FIgURE 1: Location map of Andhra Pradesh in India.

a requirement of national level precise burnt area assessment using high-and moderate-resolution satellite data in addressing the various issues like reliable assessment in terms of area, number of patches and spatial spread, base line information for temporal monitoring and fire recurrence assessment, identification and prioritization of vulnerable areas, understanding the impacts on regeneration, succession, biodiversity and wildlife, assessment in terms of Green House Gas Emissions towards national communication, scope for developing web enabled national forest burnt area reporting system, and fire mitigation planning [1-13].

Technological advancement of satellite remote sensing both in spatial and spectral sensors is a cost- and time-effective solution in identifying areas for biodiversity conservation. Currently several satellite-based sensors like AWiFS, LISS-III, MODIS, $\mathrm{ETM}^{+}$, SPOT, AATSR, AVHRR, and MODIS provide synergistic datasets that have potential in forest fire detection, inventory, mapping, and damage assessment [1]. Forest burnt areas have a typical spectral signature, especially if analysed by a multitemporal approach because of the different ground coverage between prefire (vegetation) and postfire (white ash, black ash, bare soil, and dead vegetation) conditions [14].

Forest fires, invasive species, and shifting cultivation are recognized as serious threat to biodiversity of many Protected Areas (PAs). Recent findings from the PAs of the tropics confirm that Lantana may be favored by fire and grazing
[15]. A critical issue is that without a clear understanding of the distribution and dynamics of forest fires, it is impossible to effectively manage them [16]. With the current trend of increasing rate of forest fires, there is an urgent need to generate a spatial database for planning, decision making, and further objective-oriented requirements. With respect to the burnt area extent and forest-type detailed information is needed in order to assess postfire ecological effects on the biodiversity.

Among the 10 biogeographic zones of India, Deccan Peninsula was found to be prone to the highest fire frequency. Among the states of Deccan Peninsula, Andhra Pradesh, Chhattisgarh, and Madhya Pradesh are regularly affected with human-induced fires. Fire occurrence information as per AATSR satellite shows maximum fires during March and April in Deccan Peninsula [17]. The estimated forest burnt area of Andhra Pradesh state was $6369 \mathrm{~km}^{2}$ during 2000 [18], which is based on coarse resolution $\left(1.1 \mathrm{~km}^{2}\right)$ SPOTVGT satellite data. In view of scanty research work on forest fires in Andhra Pradesh, the present study was focused on assessment and inventory of forest fires covering number of fires, burnt area size, annual area burned, and distribution across forest types using IRS P6 AWiFS data for the 2009. In the present study, an attempt was also made to generate the information on forest burnt areas across the districts, Protected Areas, and elevation zones of Andhra Pradesh. 


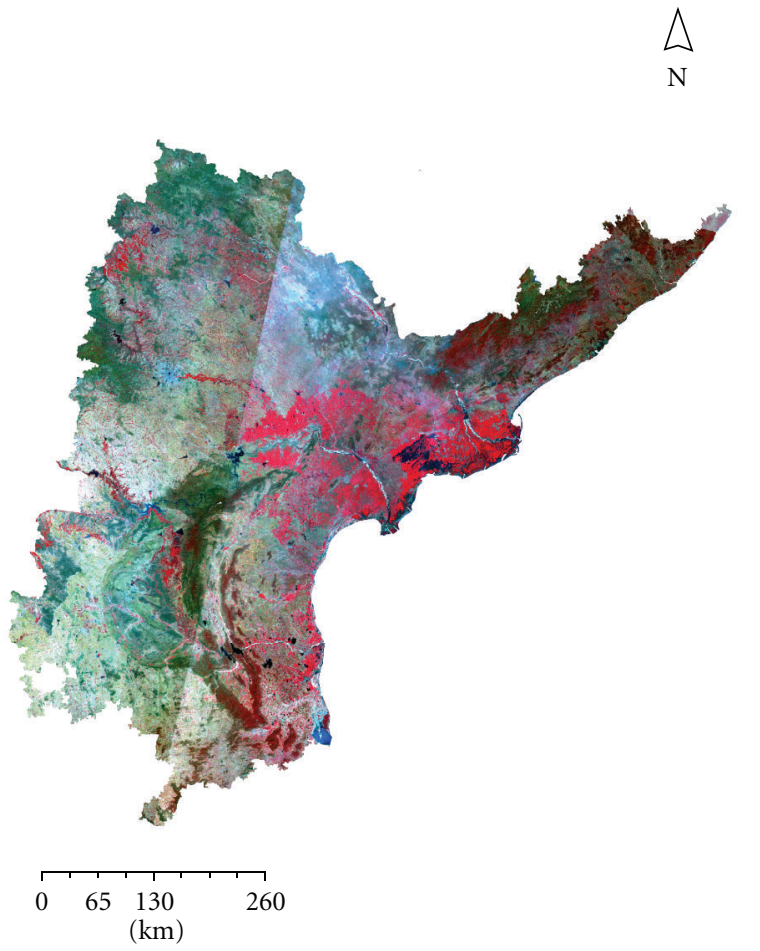

Figure 2: IRS P6 AWiFS FCC image of Andhra Pradesh (March, 2009).

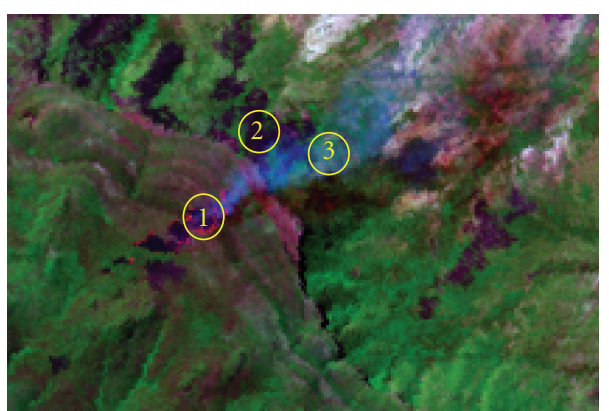

Figure 3: Active burnt and after fire signatures on IRS P6 AWiFS image (4,3,2 band combination) of March 7th, 2009. (1) Active fire area (2) postfire area (3) smoke.

\section{Materials and Methods}

2.1. Study Area. The State of Andhra Pradesh is situated in the middle of eastern half of the Indian Peninsula lying between $12^{\circ} 41^{\prime}-19^{0} 54^{\prime} \mathrm{N}$ latitudes and $76^{\circ} 46^{\prime}-84^{0} 45^{\prime} \mathrm{E}$ longitudes (Figure 1). It is India's fourth largest state by area and fifth largest by population. It is bounded by the Bay of Bengal in the east, Tamil Nadu in the south, Karnataka in the west, and Maharashtra, Chhattisgarh, and Orissa in the north. Andhra Pradesh receives most of its annual rainfall from the south-west monsoon as well as from the north-east monsoon. The south-west monsoon begins in the second

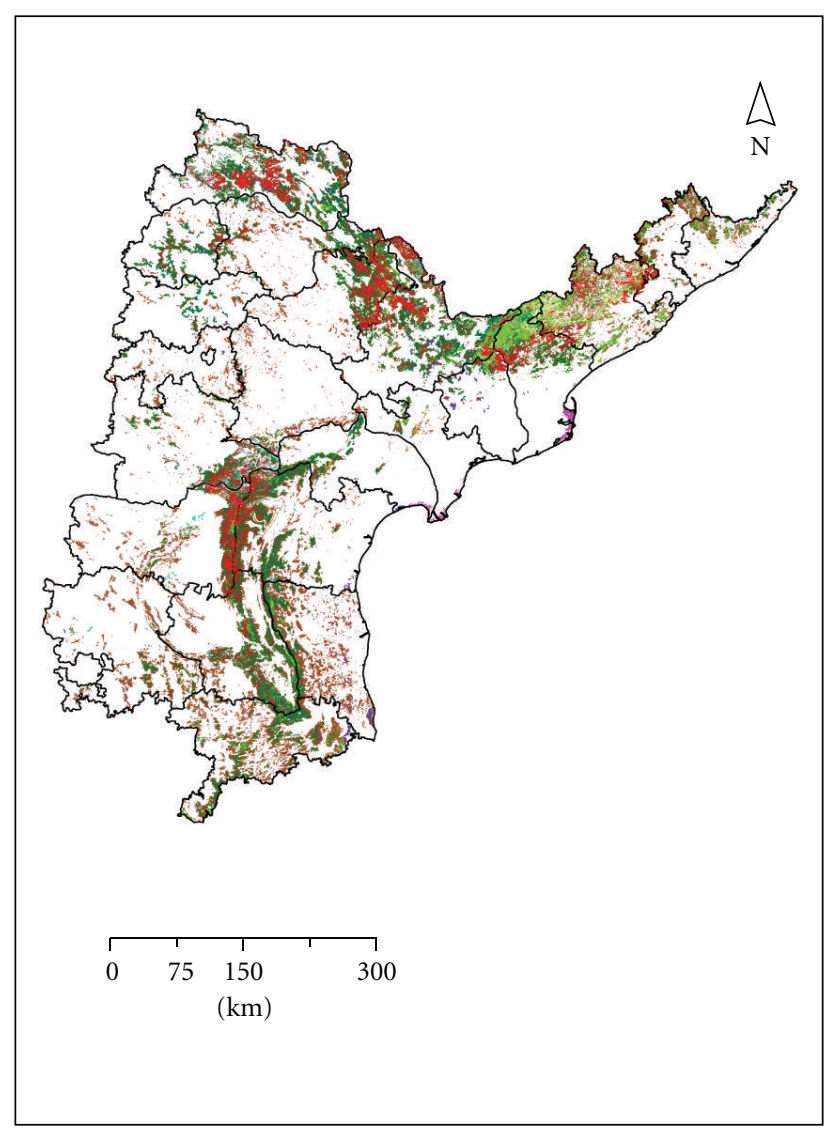

Forest burnt area Semi evergreen forest Moist Deciduous forest Dry Deciduous forest Dry Evergreen forest Thorn forest Teak mixed forest Bamboo mixed forest

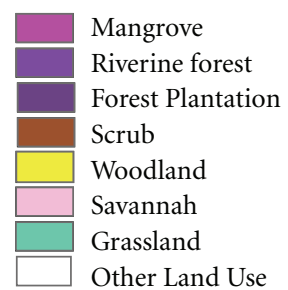

Figure 4: Forest burnt areas overlaid on forest-type map of Andhra Pradesh.

week of June and lasts till September while the northeast monsoon descends between October and November. The state experiences a mild winter in December but the temperature hardly goes down below $16^{\circ} \mathrm{C}$. The hot season prevails in the months of March, April, and May when it could shoot up to 40 degrees or even higher.

Geographically, the state is categorized into three regions, namely, (1) the Coastal Plains (along the east coast, a low-lying area from from Srikakulam to Nellore) mainly of agricultural land, (2) the Eastern Ghats, forming a chain of discontinuous range of hills along the coast with good vegetation, and (3) the Deccan Plateau consisting of agricultural lands, scrub, and deciduous forests, which cover part of Kurnool (excl. Nallamalais), Anantapur districts (excl. Nigidi hills), and the major part of Telangana. The total forest cover of the state is $45,102 \mathrm{~km}^{2}$, which occupies $16.4 \%$ of the total geographical area of $275,068 \mathrm{~km}^{2}$ (FSI, 2009). 


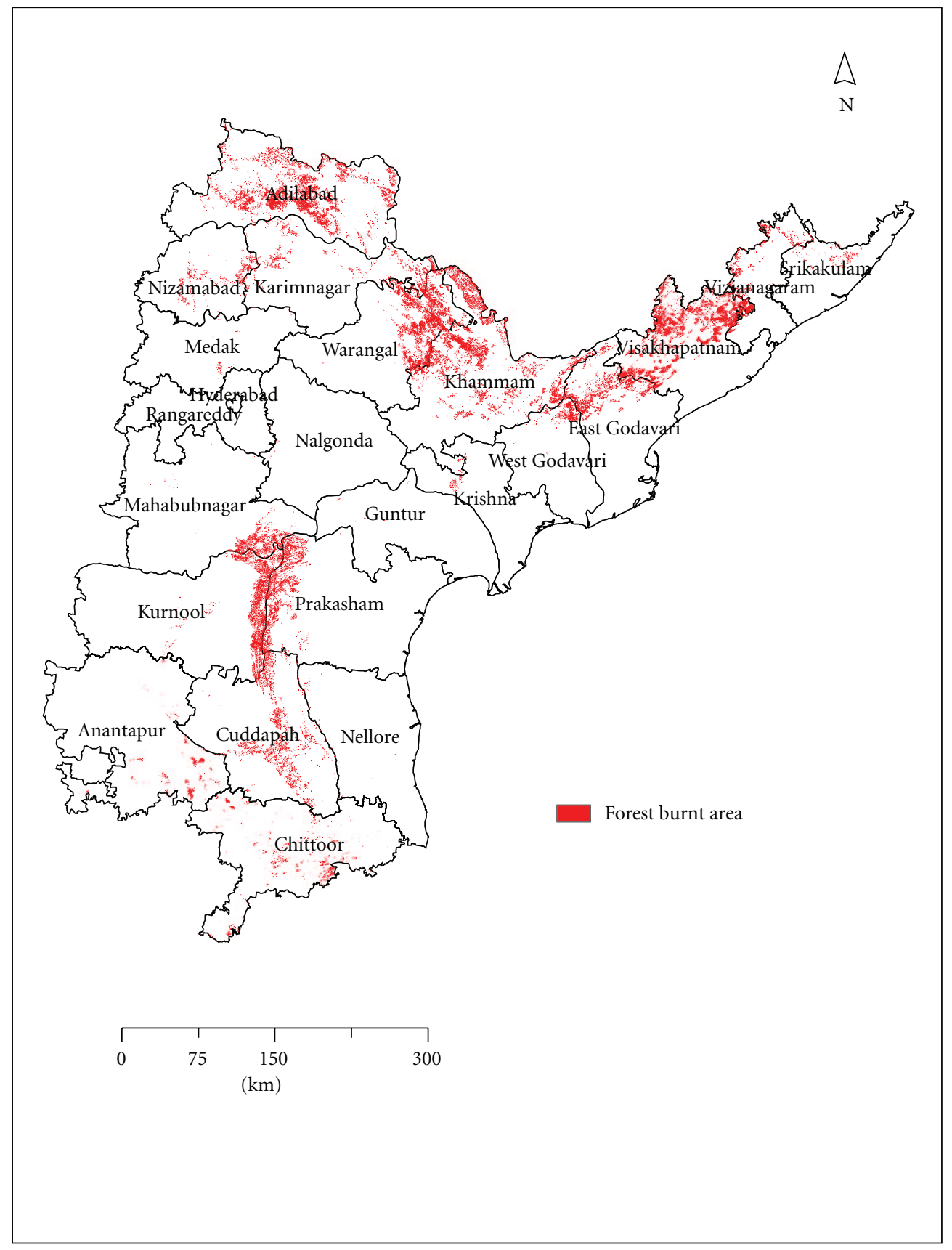

Figure 5: Forest burnt areas overlaid on district map of Andhra Pradesh.

There are 27 Protected Areas declared for conservation in Andhra Pradesh, comprising 22 wildlife sanctuaries and 5 national parks. The total area protected for biodiversity is about $12,555 \mathrm{~km}^{2}$ or $4.56 \%$ of geographical area of Andhra Pradesh. Nagarjunasagar Srisailam Tiger Reserve is largest tiger reserve of the country, it occupies $28 \%$ of the total Protected Area of Andhra Pradesh [19].

2.2. Remote Sensing Data. Indian Remote Sensing Satellite P6 (ResourseSat-1) AWiFS sensor has spatial resolution of $56 \mathrm{~m}$ and radiometric resolution of 10-bit. AWiFS operates in four spectral bands in the green $(0.52-0.59 \mu \mathrm{m})$, red $(0.62-$ $0.68 \mu \mathrm{m})$, Near IR $(0.77-0.86 \mu \mathrm{m})$, and Short-Wave IR (1.55$1.70 \mu \mathrm{m})$. It has a swath width of $740 \mathrm{~km}$ and a revisit period of five days. Cloud free IRS-P6 AWiFS data pertaining to January, February, March, and April 2009 were selected for the study. AWiFS data were geometrically rectified with an average of less than one pixel accuracy using ERDAS Imagine 9.3. Orthorectified Landsat ETM+ datasets were downloaded from Global Land Cover Facility for reference [20]. To reduce the error due to various atmospheric conditions at different dates of image acquisition conversion 


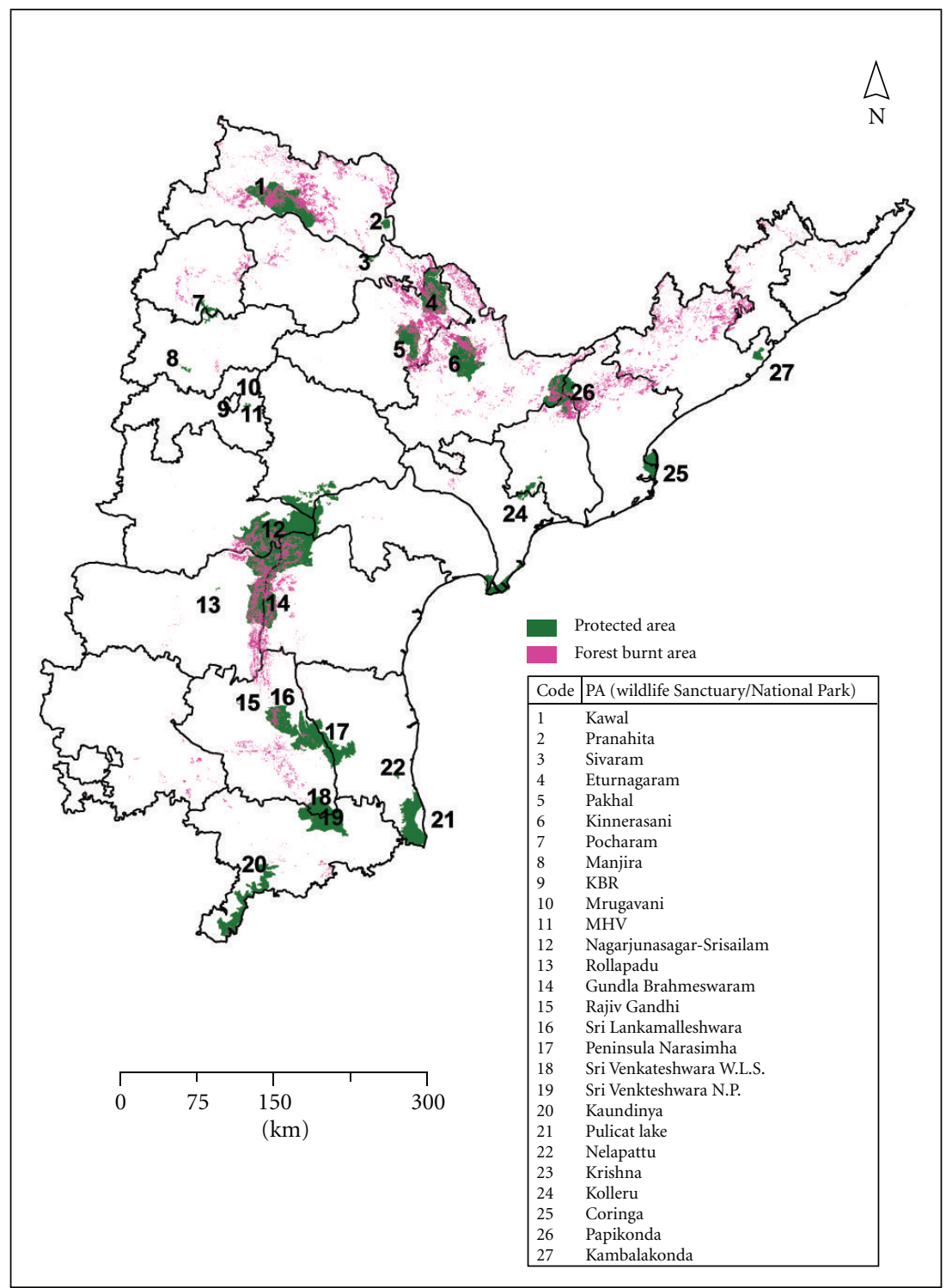

FIgURE 6: Forest burnt areas overlaid on Protected Area map of Andhra Pradesh.

of digital number to Top-of-Atmosphere (TOA) reflectance as suggested by Chavez [21] was followed. The raw digital data were enhanced using contrast stretching and ratiobased techniques to facilitate better discrimination of forest burnt areas and other land cover. The four spectral bands of AWiFS sensor can be used for a different observational task during and after a fire incidence. SWIR, NIR, and Red spectral bands were assigned to respective red, green, and blue gun to highlight source point of active fire (Figure 3). More specifically, fire plumes and burnt areas can be better distinguished in the SWIR spectral channel for detecting high temperature targets. Since $1.65 \mu \mathrm{m}$ in the electromagnetic spectrum is very sensitive to flame and flaming energy and not very sensitive to smoldering and its energy, FCC with the SWIR, NIR, and R combination highlights the active fire pixels. SWIR channel is considered more suitable for identifying hotspots, since the maximum
Planck black body radiance shifts to shorter wavelengths as temperature increases. The usefulness of the SWIR channel has long been recognized for monitoring forest fires $[1,13]$.

2.3. Ancillary Data and Software Packages. The ancillary data were used for reference from Global Positioning System (GPS), the Survey of India (SOI) topographical sheets of $1: 50,000$ scale, and IRS P6 LISS III image data of December 2003/January 2004. The software packages used were ArcGIS and Erdas Imagine.

2.4. Burnt Area Mapping and Analysis. The vegetation-type maps are primary inputs for identification of forest fire risk. Vegetation-type map of 1:50,000 scale prepared as part of national project of biodiversity characterisation at landscape level was used in the study to understand the distribution of various forest types and to integrate in GIS 


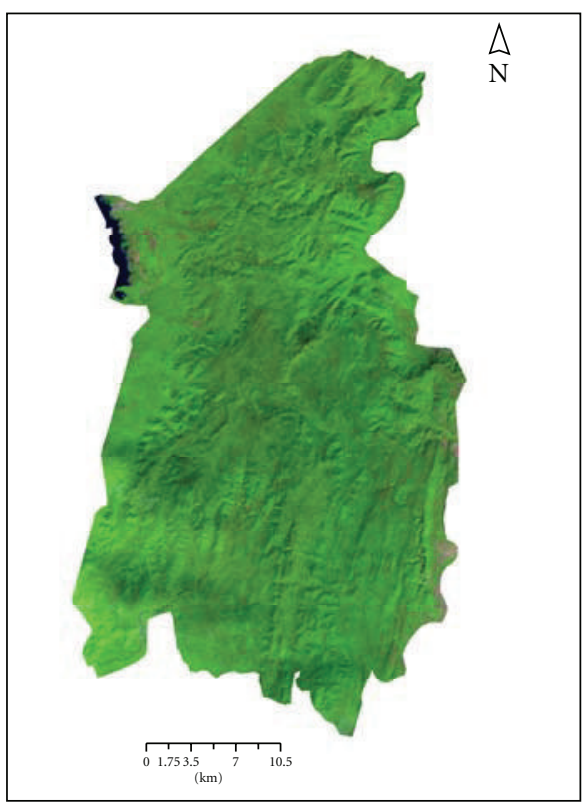

(a) Natural Colour Composite image (2-Jan-2009)

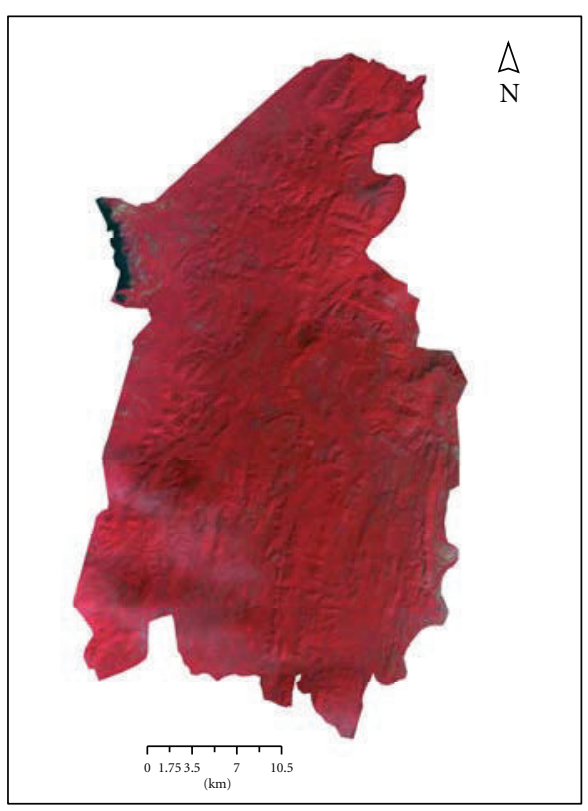

(c) False Colour Composite image (2-Jan-2009)

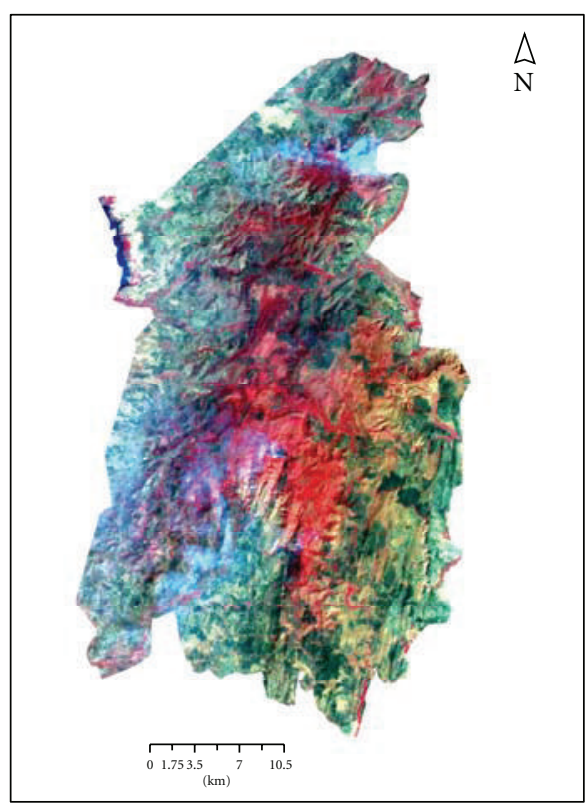

(b) False Colour Composite image (7-Mar-2009)

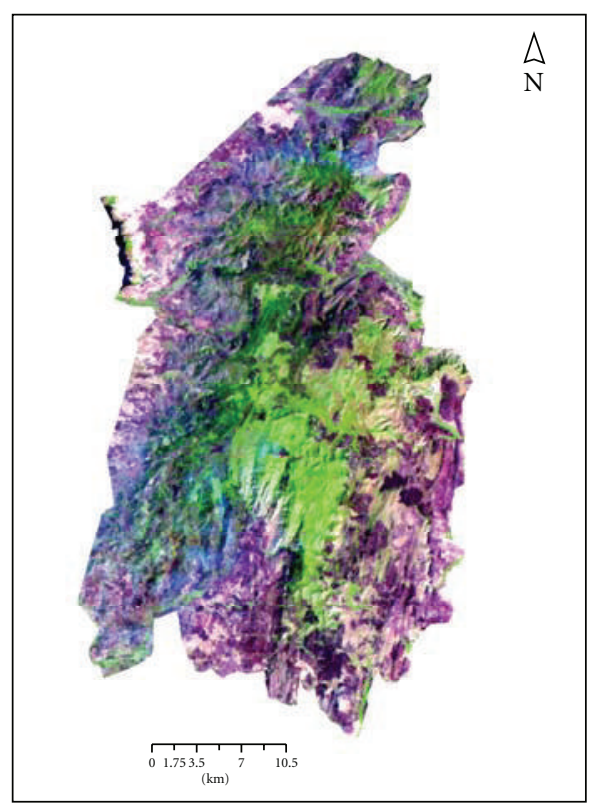

(d) Natural Colour Composite image (7-Mar-2009)

Figure 7: Multi-temporal IRS P6 AWiFS images of Gundla Brahmeswaram Sanctuary (no fires were observed in (a) and (c); high fire occurrence noticed in (b) and (d)).

analysis [21]. IRS P6 AWiFS Imagery was classified digitally by the technique of supervised classification using maximum likelihood classifier, with appropriate signatures/training sets for mapping forest burnt areas and land cover categories. The spectral separability and contingency analysis of training sites indicated that burnt pixels were distinct, and more than $96 \%$ of the pixels in the training sites were correctly classified. All the nonforest classes, namely, scrub, agriculture, settlement, barren, fallow, and water bodies were masked out using vegetation-type map. Finally, burnt pixels overlaid on different forest types to assess area under forest fire. The spatial information generated on forest burnt areas was utilized to understand the distribution of fires across the districts, Protected Areas. Fire occurrence analysis was carried out to understand the fire frequency from the forest edge to interior and disturbance sources. The Aster global DEM was used to find out distribution of forest fire across elevation zones [22]. Testing samples have been selected from the reference field data for assessing the classification accuracy. 
TABLE 1: Areal extent of forest types and proportion of burnt area in each forest type of Andhra Pradesh, India.

\begin{tabular}{llccc}
\hline No. Class & $\begin{array}{c}\text { Forest area } \\
\left(\mathrm{km}^{2}\right)\end{array}$ & $\begin{array}{c}\text { Forest } \\
\text { burnt area } \\
\left(\mathrm{km}^{2}\right)\end{array}$ & $\begin{array}{c}\text { \% of } \\
\text { forest } \\
\text { burnt area }\end{array}$ \\
\hline 1 & Semievergreen forest & 1585.4 & 185.0 & 11.7 \\
2 & Moist deciduous forest & 4865.9 & 955.5 & 19.6 \\
3 & Dry deciduous forest & 32524.0 & 6163.1 & 18.9 \\
4 & Thorn forest & 66.4 & 4.5 & 6.8 \\
5 & Dry evergreen forest & 221.6 & 0.1 & 0.02 \\
6 & Teak mixed forest & 461.1 & 134.6 & 29.2 \\
7 & Bamboo mixed forest & 654.0 & 210.9 & 32.2 \\
8 & Riverine forest & 1209.1 & 204.8 & 16.9 \\
9 & Forest plantation & 1157.0 & 33.1 & 2.9 \\
10 & Savannah/woodland & 2028.5 & 702.0 & 34.6 \\
11 & Mangrove & 329 & 0.0 & 0.0 \\
\hline & Grand total & 45102 & 8593.5 & 19.1 \\
\hline
\end{tabular}

\section{Results and Discussion}

IRS P6 AWiFS False Colour Composite image of Andhra Pradesh was shown in Figure 2. The forest types found in Andhra Pradesh are semievergreen, moist deciduous, dry deciduous, dry evergreen, thorn, teak mixed, bamboo mixed, riverine forest, mangrove, and savannah. Most abundant forest type was dry deciduous forest which comprises $32524 \mathrm{~km}^{2}$ of the total forest area, followed by moist deciduous forest of $4865.9 \mathrm{~km}^{2}$ (Table 1). The forest fires in Andhra Pradesh are mostly ground fires which are usually confined to the vegetation of the lower canopy destroying shrubs and herbs and also scorch the tree bases. Surface fires are also frequent and associated with ground fires, which burn the shrubs and trees of the middle canopy. The spatial analysis of fire occurrence and extent of forest fires in 2009 was presented below.

3.1. Forest-Type Wise Burnt Area. Table 1 shows the forest type wise assessment of burnt areas. Almost 19.1\% $\left(8593.5 \mathrm{~km}^{2}\right)$ of total forest cover of Andhra Pradesh was affected by fires during 2009. It was also determined that there have been significant increases of forest burnt area as compared to 2000 (an area of $6369 \mathrm{~km}^{2}$ in 2000 to an area of $8593.5 \mathrm{~km}^{2}$ in 2009). The net increase of burnt area of $2224.5 \mathrm{~km}^{2}$ within a decade infers considerable rising threat to forest environment. All the inland forest types were undergone fire during 2009 (Figure 4). The forest type and species composition are decisive factors in forest fires. Among the different forest types, savannah/woodland undergone a large-scale forest fire which was accounted as $34.6 \%$, followed by bamboo mixed forest $(32.2 \%)$ and teak mixed forest $(29.2 \%)$. But, the highest spatial extent of forest fires was noticed in dry deciduous forests and moist deciduous forests. Presently the moist deciduous forests in northern parts of Andhra Pradesh are under threat due to slash and burn agriculture. So, proportionately slightly

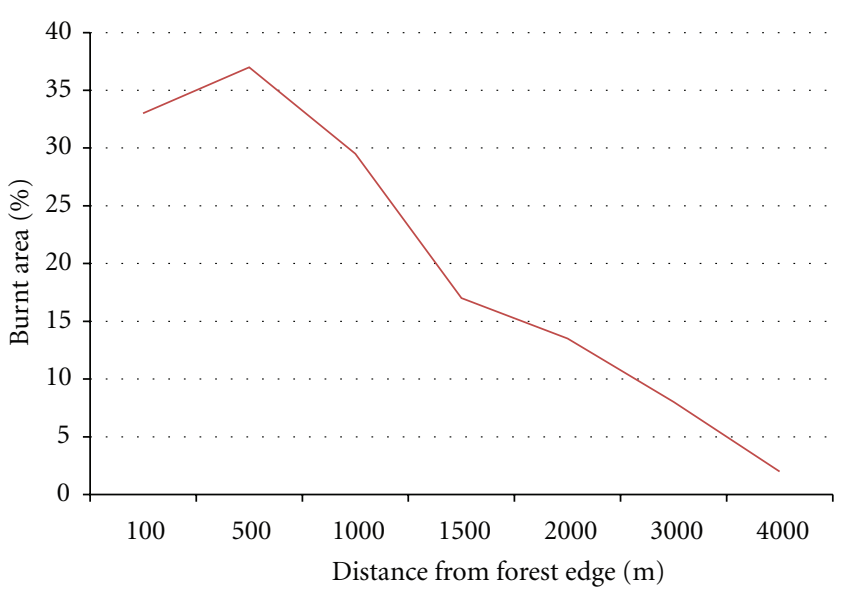

FIGURE 8: Pattern of fire frequency in relation to distance from forest edges to interior.

more burnt area has been accounted in moist deciduous forests as compared to dry deciduous forests. The study also found dry deciduous forests are more vulnerable to fires than thorn forests. The reason could be thorn forests are receiving very low rainfall and hence insignificant amount of combustible matter is available. About $11.7 \%$ of area of semi evergreen forests are also undergone fire indicates conservation threat to high biologically richness areas of Andhra Pradesh. Dry evergreen forests which are distributed in Krishna and Guntur are less affected due to fire. Riverine (riparian) forests are also affected by fire in summer due to drying of streams.

3.2. District Wise Forest Burnt Area. Administratively, Andhra Pradesh has 23 districts which were grouped into three zones: (1) Coastal Andhra, (2) Rayalaseema, (3) Telangana. On the whole, forest burnt area in Telangana region was very high $\left(4637.7 \mathrm{~km}^{2}\right)$, followed by Coastal Andhra $\left(2502.1 \mathrm{~km}^{2}\right)$ and Rayalaseema $\left(1453.7 \mathrm{~km}^{2}\right)$. As compared to Rayalaseema region, Telangana receives moderately high rainfall, but represents more forest fires reveals severe anthropogenic pressure (Figure 5). Among the 23 districts, Adilabad, Khammam, Warangal, Kurnool, Visakhapatnam, Vizianagaram, and Prakasham were evidenced with largescale fires (Table 2). Of the total forest burnt area at state level, Adilabad, Khammam, and Warangal are representing highest area and estimated as $16.8 \%, 14.9 \%$, and $12.9 \%$, respectively. According the proportionate burnt area with reference to forest cover, Kurnool was affected by more fire (39.9\%) followed by Warangal (35.9\%), Adilabad (23.8\%), Visakhapatnam (23.3\%), Vizianagaram (22.9\%), and Prakasham (22.8\%).

3.3. Protected Area Wise Forest Burnt Area. Taking into account the wildlife sanctuaries and national parks, the total area affected by forest fires during 2009 are $2680.5 \mathrm{~km}^{2}$ (23.6\%). Of the 11 Protected Areas in Eastern Ghats, Papikonda wildlife sanctuary and Gundla Brahmeswaram wildlife sanctuary were affected $49.4 \%$ and $41.7 \%$ of 
TABle 2: Region- and district-wise forest burnt area statistics of Andhra Pradesh: 2009.

\begin{tabular}{|c|c|c|c|c|c|}
\hline District & $\begin{array}{l}\text { Geographical } \\
\text { area }\left(\mathrm{km}^{2}\right)\end{array}$ & $\begin{array}{c}\text { Forest cover } \\
\left(\mathrm{km}^{2}\right)\end{array}$ & $\begin{array}{c}\text { Forest burnt } \\
\text { area }\left(\mathrm{km}^{2}\right)\end{array}$ & $\begin{array}{c}\% \text { of burnt } \\
\text { area/forest cover }\end{array}$ & $\begin{array}{c}\% \text { of state forest } \\
\text { burnt area }\end{array}$ \\
\hline \multicolumn{6}{|c|}{ (A) Telangana } \\
\hline Adilabad & 16128 & 6084 & 1446.5 & 23.8 & 16.8 \\
\hline Khammam & 16029 & 7112 & 1281.5 & 18 & 14.9 \\
\hline Warangal & 12847 & 3091 & 1110.5 & 35.9 & 12.9 \\
\hline Mahabubnagar & 18432 & 1944 & 338.1 & 17.4 & 3.9 \\
\hline Karimnagar & 11823 & 1683 & 278.5 & 16.5 & 3.2 \\
\hline Nizamabad & 7956 & 1198 & 163.1 & 13.6 & 1.9 \\
\hline Medak & 9700 & 586 & 17.5 & 3 & 0.2 \\
\hline Nalgonda & 14240 & 151 & 1.9 & 1.3 & 0.02 \\
\hline Hyderabad and Rangareddy & 7710 & 391 & 0 & 0 & 0 \\
\hline Subtotal & 114865 & 22240 & 4637.7 & 20.9 & 54.0 \\
\hline \multicolumn{6}{|c|}{ (B) Rayalaseema } \\
\hline Kurnool & 17658 & 2131 & 850.3 & 39.9 & 9.9 \\
\hline Cuddapah & 15359 & 3409 & 507.8 & 14.9 & 5.9 \\
\hline Anantapur & 19130 & 426 & 71.4 & 16.8 & 0.8 \\
\hline Chittoor & 15151 & 2399 & 24.2 & 1 & 0.3 \\
\hline Subtotal & 67298 & 8365 & 1453.7 & 17.4 & 16.9 \\
\hline \multicolumn{6}{|c|}{ (C) Coastal Andhra } \\
\hline Visakhapatnam & 11161 & 3445 & 801.9 & 23.3 & 9.3 \\
\hline Prakasham & 17626 & 3104 & 708.2 & 22.8 & 8.2 \\
\hline East Godavari & 10807 & 3561 & 520.7 & 14.6 & 6.1 \\
\hline West Godavari & 7742 & 909 & 196.9 & 21.7 & 2.3 \\
\hline Vizianagaram & 6539 & 749 & 171.8 & 22.9 & 2.0 \\
\hline Srikakulam & 5837 & 616 & 68.7 & 11.1 & 0.8 \\
\hline Krishna & 8727 & 313 & 24.2 & 7.7 & 0.3 \\
\hline Nellore & 13076 & 937 & 6.1 & 0.6 & 0.1 \\
\hline Guntur & 11391 & 863 & 3.6 & 0.4 & 0.04 \\
\hline Subtotal & 92906 & 14497 & 2502.1 & 17.3 & 29.1 \\
\hline Grand total & 275069 & 45102 & 8593.5 & 19.1 & 100 \\
\hline
\end{tabular}

area, respectively. Nagarjunasagar Srisailam Tiger Reserve is largest tiger reserve in India, shows $792.5 \mathrm{~km}^{2}(22.2 \%)$ area under forest fire (Figures 5, 6, and 7). Of the eight wildlife sanctuaries in Deccan Plateau (Telangana), Kawal, Eturnagaram, and Kinnersani were affected by more fires. The forest fires were not noticed in small Protected Areas that is, Rollapadu sanctuary, Rajiv Gandhi national park, Kambalakonda sanctuary, Manjira sanctuary, KBR national park, Mrugavani national park, and MHV national park during 2009. It is attributed to stringent conservation measures. But these seven Protected Areas contribute to about 1\% of total Protected Area network of Andhra Pradesh (Table 3). Prescribed fire is an important tool for managing habitats and the wildlife populations. Tender shoots from resprouting saplings and shrubs are highly nutritious and attract many herbivores. But uncontrolled fires in tiger reserve and other protected areas can have extreme effects on native biodiversity and may provide an opportunity to invasive alien species to colonise.
3.4. Elevation Zone Wise Forest Burnt Area. Forest fire occurrence was analysed across elevation (altitudinal) gradient (Table 4). Forest fires were very high in elevation range of above $1200 \mathrm{~m}$, which mostly represents savannah/woodland ecosystems. The low elevation $(<200 \mathrm{~m})$ forests of Chittoor, Nellore, Krishna, Guntur, and Srikakulam were affected by less fire occurrence as compared to elevation zone of 200-600 m. The areas with southern aspect and high slope ( $>30 \%$ ) were found to be more sensitive for fire spread.

3.5. Forest Burnt Area Patches. The numbers of burnt area patches are found to be 9592. Forest burnt area patches of different size categories were analysed (Table 5). Patch size analysis of forest burnt areas revealed the information that the maximum number (6601) of burnt area patches are under 25 ha. Interestingly the burnt area class of $>400$ ha shows $5545.3 \mathrm{~km}^{2}(64.5 \%)$ of total burnt area followed by $<25$ ha class with representation of $741.1 \mathrm{~km}^{2}(8.6 \%)$ of area. 
TABle 3: Areal extent of forest burnt areas in Protected Areas of Andhra Pradesh.

\begin{tabular}{|c|c|c|c|c|}
\hline No. & Protected Area & Area $\left(\mathrm{km}^{2}\right)$ & Forest burnt area $\left(\mathrm{km}^{2}\right)$ & $\%$ of forest burnt area \\
\hline \multicolumn{5}{|c|}{ (I) Eastern Ghats region } \\
\hline 1 & Nagarjunasagar Srisailam Tiger Reserve & 3568 & 792.5 & 22.2 \\
\hline 2 & Gundla Brahmeswaram & 1194 & 497.8 & 41.7 \\
\hline 3 & Rollapadu & 6.14 & 0.0 & 0.0 \\
\hline 4 & Rajiv Gandhi national park & 2.3 & 0.0 & 0.0 \\
\hline 5 & Peninsula Narasimha & 1030.85 & 28.1 & 2.7 \\
\hline 6 & Sri Lankamalleshwara & 464.42 & 73.1 & 15.7 \\
\hline 7 and 8 & S.V. Wildlife sanctuary and national park & 525.97 & 1.5 & 0.3 \\
\hline 9 & Kaundinya & 357.6 & 17.0 & 4.7 \\
\hline 10 & Papikonda & 591.4 & 291.9 & 49.4 \\
\hline 11 & Kambalakonda & 70.7 & 0.0 & 0.0 \\
\hline & Subtotal & 7811.38 & 1701.8 & 21.8 \\
\hline \multicolumn{5}{|c|}{ (II) Deccan Plateau region } \\
\hline 1 & Kawal & 893 & 375.9 & 42.1 \\
\hline 2 & Pranahita & 136.02 & 1.5 & 1.1 \\
\hline 3 & Sivaram & 29.81 & 2.1 & 7.1 \\
\hline 4 & Kinnerasani & 635.4 & 179.3 & 28.2 \\
\hline 5 & Eturnagaram & 803 & 279.4 & 34.8 \\
\hline 6 & Pakhal & 860.2 & 140.2 & 16.3 \\
\hline 7 & Manjira & 20 & 0.0 & 0.0 \\
\hline 8 & Pocharam & 129.8 & 0.3 & 0.3 \\
\hline 9 & KBR national park & 1.425 & 0.0 & 0.0 \\
\hline 10 & Mrugavani national park & 3.6 & 0.0 & 0.0 \\
\hline \multirow[t]{3}{*}{11} & MHV National Park & 14.59 & 0.0 & 0.0 \\
\hline & Subtotal & 3526.89 & 978.7 & 27.8 \\
\hline & Grand total & 11338.27 & 2680.5 & 23.6 \\
\hline
\end{tabular}

TABLE 4: Areal extent of forest burnt area across elevation zones.

\begin{tabular}{lcccc}
\hline Sl. no. & $\begin{array}{c}\text { Elevation } \\
\text { zone }(\mathrm{m})\end{array}$ & $\begin{array}{c}\text { Forest area } \\
\left(\mathrm{km}^{2}\right)\end{array}$ & $\begin{array}{c}\text { Forest burnt } \\
\text { area }\left(\mathrm{km}^{2}\right)\end{array}$ & $\begin{array}{c}\text { \% of burnt } \\
\text { area }\end{array}$ \\
\hline 1 & $<200$ & 9673.6 & 1137.7 & 11.8 \\
2 & $201-400$ & 15023.5 & 3477.7 & 23.1 \\
3 & $401-600$ & 12947.7 & 2522.8 & 19.5 \\
4 & $601-800$ & 5002.0 & 935.8 & 18.7 \\
5 & $801-1000$ & 1482.1 & 241.1 & 16.3 \\
6 & $1001-1200$ & 713.9 & 172.1 & 24.1 \\
7 & $1201-1400$ & 225.2 & 90.6 & 40.2 \\
8 & $1401-1527$ & 34.0 & 15.7 & 46.1 \\
\hline & Grand total & 45102 & 8593.5 & 19.1 \\
\hline
\end{tabular}

3.6. Correlation of Fire Frequency to Forest Edge and Settlements. GIS analysis of fire frequency from the forest edge to interior and disturbance sources (settlements) reveals fires were prevalent in edge forests as compared to core forests. Fire frequency was very high at a distance of $500 \mathrm{~m}$ from forest edge (Figure 8 ) which fell down to nearly zero percentage of burnt area by $4000 \mathrm{~m}$. This could be attributed to man made activities outside their settlement areas, and in general anthropogenic origin forest fire in the state.
TABle 5: Size class distribution of forest burnt areas in Andhra Pradesh.

\begin{tabular}{lccccc}
\hline $\begin{array}{l}\text { Sl. } \\
\text { no. }\end{array}$ & $\begin{array}{c}\text { Burnt area } \\
\text { patch size (ha.) }\end{array}$ & $\begin{array}{c}\text { No. of } \\
\text { patches }\end{array}$ & $\begin{array}{c}\text { Area } \\
\left(\mathrm{km}^{2}\right)\end{array}$ & $\begin{array}{c}\text { \% of } \\
\text { patches }\end{array}$ & $\begin{array}{c}\text { \% of burnt } \\
\text { area }\end{array}$ \\
\hline 1 & $<25$ & 6601 & 741.1 & 68.8 & 8.6 \\
2 & $26-50$ & 1291 & 462.5 & 13.5 & 5.4 \\
3 & $51-100$ & 728 & 513.7 & 7.6 & 6.0 \\
4 & $101-200$ & 446 & 621.7 & 4.6 & 7.2 \\
5 & $201-300$ & 167 & 413.7 & 1.7 & 4.8 \\
6 & $301-400$ & 85 & 295.5 & 0.9 & 3.4 \\
7 & $>400$ & 274 & 5545.3 & 2.9 & 64.5 \\
\hline & Grand total & 9592 & 8593.5 & 100 & 100 \\
\hline
\end{tabular}

Using random statistics techniques, overall classification accuracy and kappa statistics were computed. The result shows an overall accuracy of classified map is $92.1 \%$ and kappa statistics is 0.91 .

\section{Conclusion}

Assessment of forest fire using satellite remote sensing indicates that about one fifth of the state's forest was under burnt area in the year of 2009. Deccan plateau and Eastern 
Ghats were the most affected phytogeographic regions in the state. Smaller protected areas were less vulnerable in comparison with larger ones attributed to the effective management existing with the small areas. Higher elevation savannahs and woodlands experienced prevalent forest fire in comparison with lower elevation areas. The study developed a forest burnt area map using remote sensing data for the conservation planning of forests in general and protected areas in particular. Spatial information generated in the present work is useful for effective forest management and ecological damage assessment.

\section{Acknowledgments}

The authors are thankful to Dr. V. Jayaraman, Former Director, NRSC, Hyderabad, Dr. V. K. Dadhwal, Director, NRSC, Hyderabad, and Dr. P. S. Roy, Director, IIRS, Dehradun for suggestions and encouragement. The work has been carried out under the national Biodiversity characterization project of Department of Space and Department of Biotechnology, Government of India.

\section{References}

[1] S. Joseph, K. Anitha, and M. S. R. Murthy, "Forest fire in India: a review of the knowledge base," Journal of Forest Research, vol. 14, no. 3, pp. 127-134, 2009.

[2] A. R. Holdsworth and C. Uhl, "Fire in Amazonian selectively logged rain forest and the potential for fire reduction," Ecological Applications, vol. 7, no. 2, pp. 713-725, 1997.

[3] FAO, 2003, http://www.fao.org/english/newsroom/news/2003/ 21962-en.html.

[4] T. P. Dawson, N. Butt, and F. Miller, "The ecology of forest fires," ASEAN Biodiversity, vol. 1, pp. 18-21, 2002.

[5] J. P. Puyravaud, J. P. Pascal, and C. Dufour, "Ecotone structure as an indicator of changing forest-savanna boundaries (Linganamakki Region, southern India)," Journal of Biogeography, vol. 21, no. 6, pp. 581-593, 1994.

[6] M. Gadgil and V. M. Meher-Homji, "Land use and productive potential of Indian Savannas," in Ecology and Management of the World's Savannas, J. C. Tothill and J. J. Mott, Eds., pp. 107-113, Australian Academy of Science, Canberra, Australia, 1985.

[7] W. Schule, "Landscapes and climate in prehistory: interactions of wildlife, man, and fire," in Fire in the Tropical Biota: Ecosystem Processes and Global Challenges, J. G. Goldammer, Ed., vol. 84 of Ecological Studies, pp. 273-318, Springer, Berlin, Germany, 1990.

[8] V. K. Bahuguna and S. Singh, "Fire situation in India," International Forest Fire News, vol. 26, pp. 23-27, 2002.

[9] K. Narendran, "Forest fires—origins and ecological paradoxes," Resonance, pp. 34-41, 2001.

[10] S. Saha, "Anthropogenic fire regime in a deciduous forest of central India," Current Science, vol. 82, no. 9, pp. 1144-1147, 2002.

[11] R. H. Beddome, “The Jeypore forests," Indian Forester, vol. 3, pp. 188-205, 1878.

[12] D. Brandis, "The forests of South India," Indian Forester, vol. 7, pp. 363-369, 1882.

[13] NRSA, "Perspectives of geoinformatics in forest fire management (Indian Forest Fire Response and Assessment System),"
Tech. Rep., National Remote Sensing Agency, Hyderabad, India, 2006.

[14] M. Marchetti and C. Ricotta, "Monitoraggio. Contributo del telerilevamento," in Incendi e complessit Ecosistemica: Dalla pianificazione forestale Al Recupero Ambientale, C. Blasi, G. Bovio, P. Corona, M. Marchetti, and A. Maturani, Eds., pp. 220-225, Ministero dellAmbiente e della Tutela del Territorio, Societa Botanica Italiana, Accademia Italiana di Scienze Forestali, Rome, Italy, 2004.

[15] A. J. Hiremath and B. Sundaram, "The fire-Lantana cycle hypothesis in Indian forests," Conservation and Society, vol. 3, pp. 26-42, 2005.

[16] J. G. Goldammer and C. de Ronde, Wild Land Fire Management Handbook for Sub-Sahara Africa, Oneworldbooks, Cape Town, South Africa, 2004.

[17] A. Giriraj, B. Shilpa, A. Jentsch, S. Sudhakar, and M. S. R. Murthy, "Tracking fires in India using advanced along track scanning radiometer (A)ATSR data," Remote Sensing, vol. 2, pp. 591-610, 2010.

[18] V. K. Prasad, K. V. S. Badarinath, and E. Anuradha, "Biophysical and anthropogenic controls of forest fires in the Deccan Plateau, India," Journal of Environmental Management, vol. 86, no. 1, pp. 1-13, 2008.

[19] C. S. Reddy, G. S. Pujar, S. Sudhakar et al., "Mapping the vegetation types of Andhra Pradesh, India using Remote Sensing," in Proceedings of the Andhra Pradesh Akademi of Sciences, vol. 12, pp. 14-23, 2008.

[20] 2009, http://glcf.umiacs.umd.edu/.

[21] P. S. Chavez, "Image-based atmospheric corrections-revisited and improved," Photogrammetric Engineering and Remote Sensing, vol. 62, no. 9, pp. 1025-1036, 1996.

[22] 2008, http://www.jspacesystems.or.jp/ersdac/GDEM/E/2.html. 

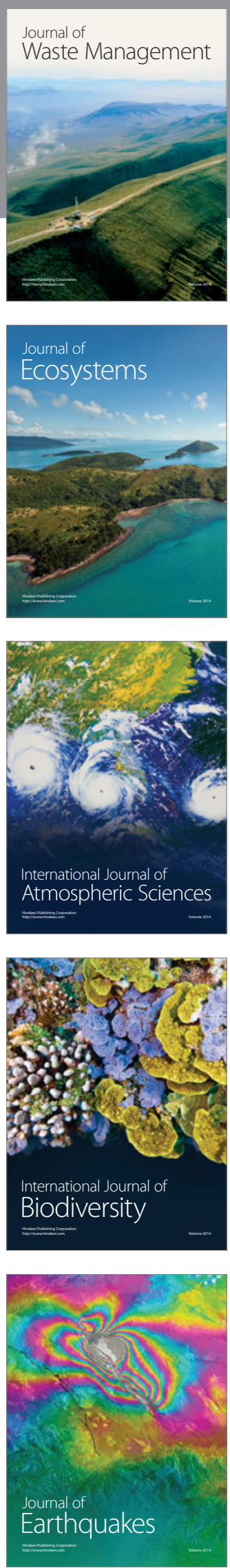
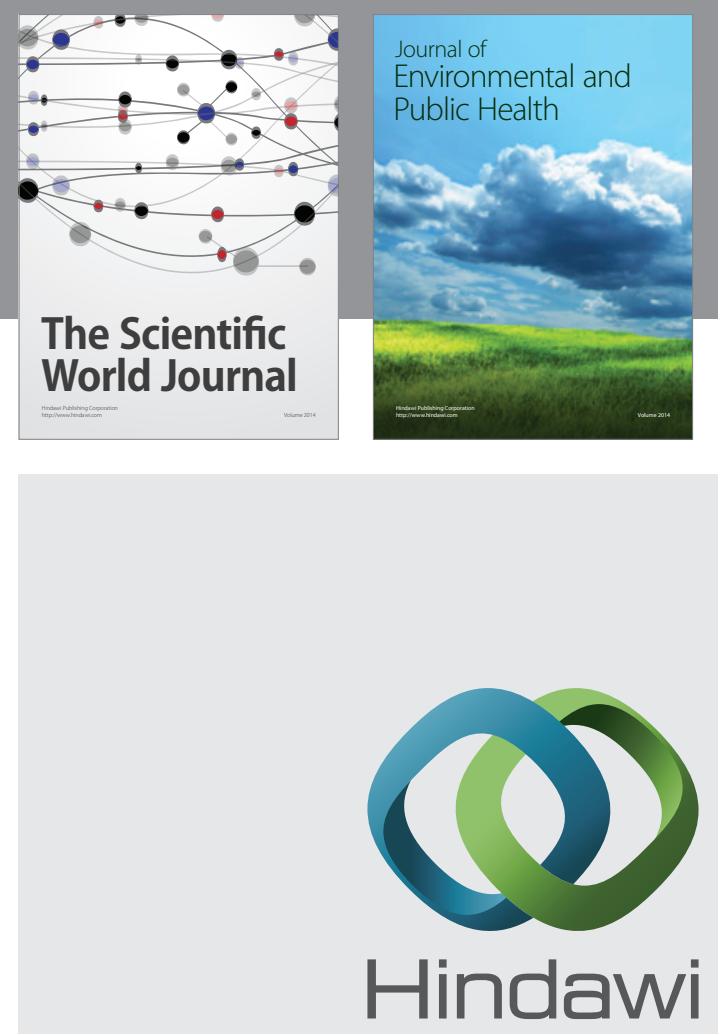

Submit your manuscripts at

http://www.hindawi.com
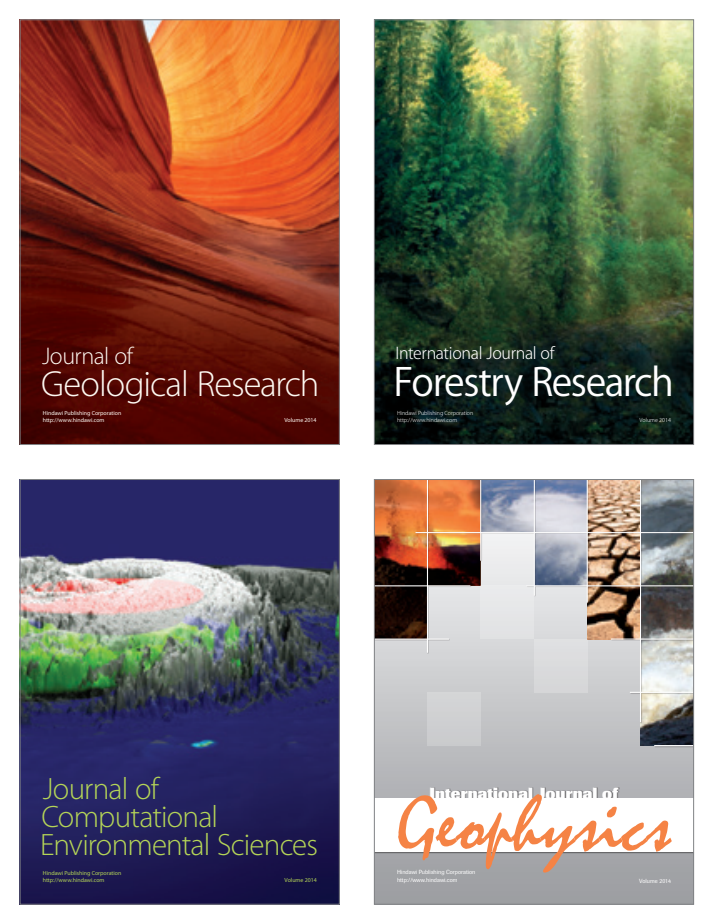
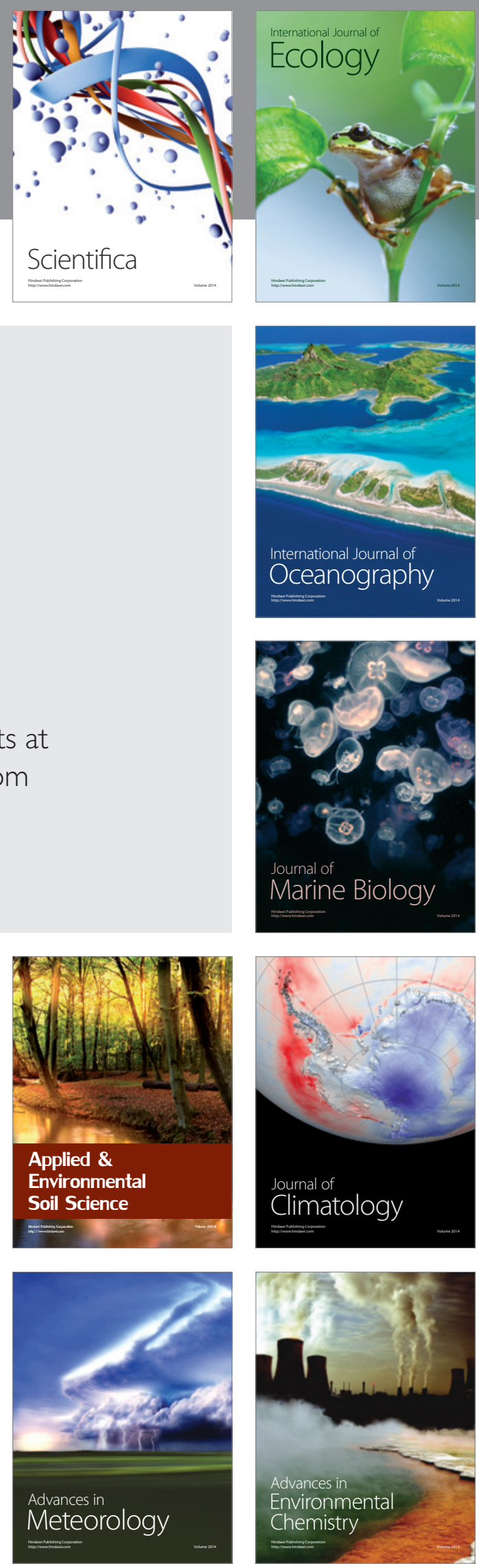